Journal of Agricultural Sciences
(Tarim Bilimleri Dergisi)

\title{
Spatial Data Model for Rural Planning and Land Management in Turkey
}

\author{
Halil Ibrahim INAN ${ }^{* *}$ (D)

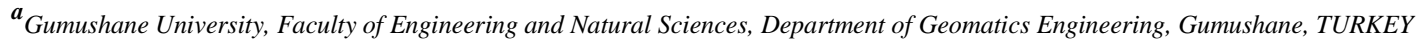 \\ ARTICLE INFO \\ Research Article \\ Corresponding Author: Halil İbrahim İnan, E-mail: hibrahim77@hotmail.com; halilibrahim.inan@gumushane.edu.tr \\ Received: 28 April 2014 / Revised: 26 April 2016 / Accepted: 16 September 2017 / Online: 04 September 2021
}

ABSTRACT

In Turkey, in the areas of rural planning and land management, problems regarding data retrieval, data quality, implementation scenario and legal base (law or regulation) have long been experienced. In this study, in order to contribute to resolving such problems, a conceptual/semantic data model was designed which focuses on the definition of required data, determination of their basic qualities and also their relations. As the preparation step for the model development, interviews, and discussions with authorized people were carried out. In addition, for the definitions of the data in the model, the Land Parcel
Identification System and Infrastructure for Spatial Information in the European Community (INSPIRE) are considered. For the model design, an object-oriented modelling method with the Unified Modelling Language (UML) notation was used. In the model, planning activities were focused on. It is envisaged that the model will guide work for the preparation of a technical regulation which may enable a standardized implementation throughout Turkey. It has also the potential to be an example for the implementation of laws related to spatial data both in Turkey and also worldwide.

Keywords: Land use planning, Agricultural land use planning, Standardization, UML, INSPIRE

(c) Ankara University, Faculty of Agriculture

\section{Introduction}

The preservation, planning and sustainability of rural areas have become more important topics worldwide when compared with agricultural production (Volker 1997; Midgley et al 2005; Pasakarnis \& Meliene 2010). In this context, the concept of rural development has gained importance (Banks \& Marsden 2000; van der Ploeg et al 2000; Elands \& Wiersum 2001; Marsden \& Sonnino 2008; Naldi et al. 2015). Despite the fact that a considerable proportion (approx. \%25) of the population in Turkey lives in rural areas (MARA 2006, UN 2019), except for traditional land consolidation activities, which are basically aimed at combining scattered land and improving irrigation facilities (Gun 2003; Cay \& Iscan 2011; Iscan 2011), integrated and comprehensive land management activities on the preservation, planning, management and sustainability of rural texture and land have not been carried out (Inan 2010). National Rural Development Plan (MARA 2011) promotes the development of technical infrastructure and social life in rural areas rather than any improvement in rural land management tools. Regional development projects (Unver 1997) and local environmental protection applications, as part of the agricultural policy implementation (Inan 2010), make a very restricted contribution to sustainable land management. As a result, integrated rural development cannot be achieved and furthermore rural land is exposed to degradation and erosion (Sarisamur \& Kilic 2011). In this context, the lack of an integrated legal base (law or regulation) was experienced until 2005. In that year, the Soil Conservation and Land Use Law (referred to hereafter in the text as the law) No 5403 (Official Gazette 2005a), which suggests integrated precautions and actions throughout the country, was enacted. This study focuses on the items (in the law) related to the inventory of rural land and soil resources, land use planning and land management. However, these items include only the main legal procedures. The definitions of required data, data quality, data processing, and data standards are not explicitly covered by the law. As for the regulation regarding the application of the law (referred to hereafter in the text as the regulation) (Official Gazette 2005b), it does not cover such definitions, either. Due to the lack of data definition, it is important, yet currently impossible, to implement the law throughout the country by complying with the same standard and quality. This study aims at providing a definition of the required data, their relations, and also the basic data processing scenario by developing a data model for rural land planning (land use plans and agricultural land use plans) and management activities in Turkey. This work was produced based on a previous study (Inan \& Yomralioglu 2011) which was presented at a national meeting in Turkey. 


\section{Material and Methods}

Data necessity analysis is the first stage of this study. In this context, the law (No 5403) and also the regulation (of the law No 5403) were analyzed; the process steps and, accordingly, the required data for these processes were determined. During this stage, processes were grouped into two classes. These were (1) compilation of available data or new data acquisition and (2) planning or land management activities.

During the necessity analysis stage, interviews, analysis, and discussions were conducted with various personnel at the Ministry of Agriculture and Forestry. In addition, common basic spatial data which are defined within the Turkish National Geographical Information System (GDLRC 2005; 2006), the Land Parcel Identification System (LPIS) as the spatial component of the Integrated Administration and Control System (Kay 2002; Goeman et al 2007; Kay \& Milenov 2007; Inan et al 2010) and Infrastructure for Spatial Information in the European Community (INSPIRE) (EC 2012) were also partly considered.

In the data model design stage, considering their geometries, data were divided into datasets and each one was represented with a class. In order not to cause complexity in terms of geometry definitions, the data geometry of few classes was defined as complex (a generic geometry type specific to this study), the geometries of the majority of classes were defined by using standardized geometry types of ISO (2003; 2019). In the model design, considering their dependencies and relations, datasets were classified into nine groups (packages).

Data necessity analysis was the basic preparation step for the data model design. The required spatial or non-spatial data were determined by considering the activities of data compilation/acquisition and processing (planning and land management), and accordingly their basic qualities/characteristics were identified (see Table 1 for common data sets and data definitions below in this section for newly defined novel data sets).

For this purpose, first of all, activities (defined in the law and regulation) related to data compilation/acquisition as well as rural land planning and management were determined. These are as follows: (1) determination of soil and land resources (item no. 7 of the law and no. 8 of the regulation), (2) classification of agricultural land (item no. 8 of the law), (3) preservation of soils (item no. 9 of the law), (4) preparation of land use plans (item no. 10 of the law and no. 9 of the regulation), (5) preparation of agricultural land use plans (item no. 11 of the law and no. 10 of the regulation), (6) preparation of soil conservation projects (item no. 12 of the law and of the regulation), (7) determination of main basins which have high agricultural potential (item no. 14 of the law), (8) determination of areas with high erosion risk (item no. 15 of the law and no. 13 of the regulation), and (9) land consolidation activities (item no. 17 of the law and no. 13 of the regulation).

Land Resources data set is required for the creation of the land use plan. It was envisaged that the data set would be produced from other data sources, which are attributed in Table 1 with "Basic Functionality" column. The data set should be produced to represent different kinds of land, such as fertile land, planted land, forests, meadows, residential areas, planned urban land, nature reserves, and non-agricultural land. The INSPIRE Data Specification does not include any data theme with similar content. In the model, land resources data set is represented in the Land Resources package with the Land Resource class.

Agricultural Land Resources data set forms a specific subset of land resource data, and is required for agricultural land use planning. It specifically includes the soil properties of agricultural land. All agricultural land throughout the country was classified by the Ministry of Agriculture and Forestry within the Determination of Problematic Agricultural Land and Their Rehabilitation project (MARA 2012). In INSPIRE Data Specification, this data set is not specifically included in any data theme. However, the related data are partially included in the Land Use and Land Cover data themes (INSPIRE 2007). In the model, it is represented in the Soil Resources package with the Agricultural Land Resource class.

Land Use Plan data set is the first product of planning activities. A spatial planning unit should be chosen beforehand. This unit may be the smallest soil surveying and mapping unit or their sub-units. In INSPIRE Data Specification, the Land Use data theme may have some similar content. In the model, it is represented in the Land Use Plan package with the Land Use Plan class. With land use plans, urban and rural lands should be allocated to land use.

Physical Block data set represents the basic spatial units for the agricultural land use plan. The data set may be produced by using ortho-photos or ortho-images in a way similar to the application of LPIS (Inan \& Cete 2007; Inan 2010; Inan et al 2010). The INSPIRE Data Specification does not define such geographic features. In the model, they are represented in the Agricultural Land Use Plan package with the Physical Block class.

Agricultural Land Use Plan data set is the second product of planning activities. The INSPIRE Data Specification does not define such a planning concept. In the model, it is represented in the Agricultural Land Use Plan package with the Agricultural Land Use Plan class. With agricultural land use plans, the appropriateness of physical blocks is decided for the type of agricultural products; (1) garden crops, (2) vegetable crops, (3) field crops, and (4) forage crops. Planning decisions should be taken by considering both technical and socio-economic factors. Planning maps and reports should include suggestions on appropriate agricultural activity, environmental protection precautions, and risks for each physical block. 
Table 1- Basic properties of necessitated data (common data sets)

\begin{tabular}{|c|c|c|c|c|c|c|c|c|}
\hline \multirow{2}{*}{$\begin{array}{l}\text { Data } \\
\text { Type }\end{array}$} & \multirow{2}{*}{$\begin{array}{l}\text { Basic } \\
\text { Functionality }\end{array}$} & \multirow{2}{*}{$\begin{array}{l}\text { Scale } \\
\text { Range }\end{array}$} & \multirow{2}{*}{$\begin{array}{l}\text { Availability } \\
\text { \& geographic } \\
\text { coverage }\end{array}$} & \multicolumn{3}{|c|}{$\begin{array}{l}\text { Relation with previous studies, LPIS and } \\
\text { INSPIRE data themes }\end{array}$} & \multicolumn{2}{|c|}{ Representation in the Data Model } \\
\hline & & & & Studies & LPIS & INSPIRE & Package & Class(es) \\
\hline $\begin{array}{l}\text { Topographic } \\
\text { Map }\end{array}$ & $\begin{array}{l}\text { Base map for } \\
\text { Land } \\
\text { Resources }\end{array}$ & $\begin{array}{l}1 / 1000 \\
1 / 10.000 \\
1 / 25.000\end{array}$ & $\begin{array}{l}\text {-Urban Areas } \\
\text {-Partial } \\
\text {-Yes }\end{array}$ & Cete 2008 & Yes & Partial & Topography & TopographicMap \\
\hline $\begin{array}{l}\text { Ortho- } \\
\text { Photo\& } \\
\text { Image }\end{array}$ & $\begin{array}{l}\text { Base map for } \\
\text { Land } \\
\text { Resources }\end{array}$ & $\begin{array}{l}1 / 2000 \\
1 / 10.000\end{array}$ & $\begin{array}{l}-\mathrm{No} \\
-\mathrm{No}\end{array}$ & $\begin{array}{l}\text { Maras et al 2011; } \\
\text { INSPIRE 2007; } \\
\text { INSPIRE 2013c }\end{array}$ & Yes & Yes & Topography & $\begin{array}{l}\text { OrthoPhoto; } \\
\text { OrthoImage }\end{array}$ \\
\hline $\begin{array}{l}\text { Digital } \\
\text { Elevation } \\
\text { Model (DEM) }\end{array}$ & $\begin{array}{l}\text { Base data for } \\
\text { slope, aspect } \\
\text { and basin } \\
\text { boundary }\end{array}$ & $1 / 25.000$ & -Yes & $\begin{array}{l}\text { Bamber et al 2001; } \\
\text { Fabris \& Pesci 2005; } \\
\text { Züblin et al 2008; } \\
\text { INSPIRE 2007; } \\
\text { INSPIRE 2013a }\end{array}$ & No & Yes & Topography & DEM \\
\hline Slope & $\begin{array}{l}\text { Base map for } \\
\text { Land } \\
\text { Resources }\end{array}$ & $1 / 25.000$ & $-\mathrm{No}$ & INSPIRE 2013a & No & Annex & Topography & Slope \\
\hline Aspect & $\begin{array}{l}\text { Base map for } \\
\text { Land } \\
\text { Resources }\end{array}$ & $1 / 25.000$ & $-\mathrm{No}$ & INSPIRE 2013a & No & No & Topography & Aspect \\
\hline $\begin{array}{l}\text { Land Parcel } \\
\text { (Property) }\end{array}$ & $\begin{array}{l}\text { Base data for } \\
\text { Land } \\
\text { Resources }\end{array}$ & $1 / 1000$ & $\begin{array}{l}\text {-Yes (with } \\
\text { data quality } \\
\text { problems) }\end{array}$ & $\begin{array}{l}\text { INSPIRE 2007; } \\
\text { INSPIRE 2010b }\end{array}$ & Yes & Yes & $\begin{array}{l}\text { Land } \\
\text { Resources }\end{array}$ & $\begin{array}{l}\text { Cadastre \& } \\
\text { Land Registry; } \\
\text { Forest Registry; } \\
\text { MeadowRegistry }\end{array}$ \\
\hline $\begin{array}{l}\text { Nature } \\
\text { Reserve }\end{array}$ & $\begin{array}{l}\text { Base data for } \\
\text { Land } \\
\text { Resources }\end{array}$ & $1 / 25.000$ & -Yes & $\begin{array}{l}\text { INSPIRE 2007; } \\
\text { INSPIRE 2010d }\end{array}$ & No & Yes & $\begin{array}{l}\text { Land } \\
\text { Resources }\end{array}$ & NatureReserve \\
\hline Zoning Map & $\begin{array}{l}\text { Base data for } \\
\text { Land } \\
\text { Resources }\end{array}$ & $\begin{array}{l}1 / 1000 \\
1 / 10.000\end{array}$ & $\begin{array}{l}\text {-Urban Areas } \\
\text {-Urban Areas }\end{array}$ & $\begin{array}{l}\text { INSPIRE 2007; } \\
\text { INSPIRE 2013g }\end{array}$ & No & Yes & $\begin{array}{l}\text { Land } \\
\text { Resources }\end{array}$ & DevelopmentPlan \\
\hline Land Cover & $\begin{array}{l}\text { Base data for } \\
\text { Land } \\
\text { Resources }\end{array}$ & $1 / 100.000$ & -Yes & $\begin{array}{l}\text { Bossard et al 2000; } \\
\text { Büttner et al 2002; } \\
\text { EEA 2010; } \\
\text { INSPIRE 2007; } \\
\text { INSPIRE 2013b }\end{array}$ & $\begin{array}{l}\text { Yes } \\
\text { (larger } \\
\text { scales) }\end{array}$ & Yes & $\begin{array}{l}\text { Land } \\
\text { Resources }\end{array}$ & LandCover \\
\hline $\begin{array}{l}\text { Administrative } \\
\text { Boundary }\end{array}$ & $\begin{array}{l}\text { Subdivision of } \\
\text { Land } \\
\text { Resources }\end{array}$ & $1 / 25.000$ & -Yes & $\begin{array}{l}\text { MARA 2012; } \\
\text { INSPIRE 2007; } \\
\text { INSPIRE 2010a }\end{array}$ & Yes & Yes & $\begin{array}{l}\text { Admin\&Basin } \\
\text { Boundary }\end{array}$ & $\begin{array}{l}\text { Administrative } \\
\text { Boundary }\end{array}$ \\
\hline $\begin{array}{l}\text { Basin } \\
\text { Boundary }\end{array}$ & $\begin{array}{l}\text { Subdivision of } \\
\text { Land } \\
\text { Resources }\end{array}$ & $1 / 25.000$ & $-\mathrm{No}$ & $\begin{array}{l}\text { INSPIRE 2007; } \\
\text { INSPIRE 2010c }\end{array}$ & No & Conceptual & $\begin{array}{l}\text { Admin\&Basin } \\
\text { Boundary }\end{array}$ & BasinBoundary \\
\hline Soil Map & $\begin{array}{l}\text { Soil } \\
\text { Classification }\end{array}$ & $\begin{array}{l}1 / 10.000 \\
1 / 25.000 \\
1 / 100.000\end{array}$ & $\begin{array}{l}-\mathrm{No} \\
-\mathrm{No} \\
-\mathrm{No}\end{array}$ & $\begin{array}{l}\text { Dinc et al 2005; } \\
\text { INSPIRE 2007; } \\
\text { INSPIRE 2013d }\end{array}$ & No & Yes & Soil Resources & SoilMap \\
\hline $\begin{array}{l}\text { Soil } \\
\text { Classification } \\
\text { Map }\end{array}$ & Planning & $\begin{array}{l}1 / 10.000 \\
1 / 25.000 \\
1 / 100.000\end{array}$ & $\begin{array}{l}\text {-No } \\
-\mathrm{No} \\
\text {-Yes }\end{array}$ & $\begin{array}{l}\text { Burrough et al } 1997 \text {; } \\
\text { O'Geen et al } 2008\end{array}$ & No & Yes & Soil Resources & SoilClassification \\
\hline $\begin{array}{l}\text { Environ- } \\
\text { mental Plan }\end{array}$ & anning & $1 / 100.000$ & -Yes & INSPIRE 2007 & No & Conceptual & $\begin{array}{l}\text { Plan\&Socio } \\
\text { Economic }\end{array}$ & EnvironmentalPlan \\
\hline $\begin{array}{l}\text { Water } \\
\text { Resources }\end{array}$ & Planning & $\begin{array}{l}1 / 10.000 \\
1 / 100.000\end{array}$ & $\begin{array}{l}-\mathrm{No} \\
-\mathrm{No}\end{array}$ & $\begin{array}{l}\text { INSPIRE 2007; } \\
\text { INSPIRE 2013e }\end{array}$ & No & Partial & $\begin{array}{l}\text { WaterResourc } \\
\text { es }\end{array}$ & WaterResource \\
\hline $\begin{array}{l}\text { Socio- } \\
\text { Economic }\end{array}$ & $\begin{array}{l}\text { Planning } \\
\text { (Attribute } \\
\text { Data) }\end{array}$ & Not Appl. & $\begin{array}{l}\text {-Yes (by } \\
\text { admin. unit) }\end{array}$ & $\begin{array}{l}\text { INSPIRE 2007; } \\
\text { INSPIRE 2013f }\end{array}$ & No & Partial & $\begin{array}{l}\text { Plan\&Socio } \\
\text { Economic }\end{array}$ & SocioEconomic \\
\hline $\begin{array}{l}\text { Rural Dev. } \\
\text { Plan }\end{array}$ & $\begin{array}{l}\text { Planning } \\
\text { (Attribute } \\
\text { Data) }\end{array}$ & Not Appl. & $\begin{array}{l}\text {-Yes (by } \\
\text { admin. unit) }\end{array}$ & MARA 2011 & No & No & $\begin{array}{l}\text { Plan\&Socio } \\
\text { Economic }\end{array}$ & $\begin{array}{l}\text { RuralDevelopment } \\
\text { Plan }\end{array}$ \\
\hline Climate & Planning & $\begin{array}{l}\text { Not Appl. } \\
1 / 25.000\end{array}$ & $\begin{array}{l}\text {-Yes (station) } \\
\text {-No (interpol.) }\end{array}$ & $\begin{array}{l}\text { Apaydin et al 2004; } \\
\text { Jolly et al } 2004\end{array}$ & No & No & Climatic & $\begin{array}{l}\text { MeteorologyStation } \\
\text { Data; Climate }\end{array}$ \\
\hline
\end{tabular}




\section{Results and Discussion}

The data model developed in this study is presented with Unified Modelling Language (UML) class diagrams (Page-Jones 2002). In recent years, this modelling method has been used for the development of both spatial data standards (ISO TC/211 and OGC) and semantic data models for spatial data infrastructures (e.g. INSPIRE and ISO 19152 LADM).

In the data model design the classes were divided into nine groups (Figure 1). Inspired by the ISO (2003, 2019) standard, the data types of the structure attribute were defined as GM_Polygon, GM_Line, GM_Point, GM_TIN, Raster and Complex. The relations between classes were defined by appropriate relation types (see sub-sections 3.2-3.10). Dependency and use relations were used to define dynamic interactions among classes. In the cases of strong and weak interactions, use and dependency relations were used, respectively. Other relations (association, aggregation, composition, and generalization/specialization) were used to define the static (logical) interaction among classes. Six types of elements were used in the model. Of these, Package represents data groups (see Figure 1), Feature Type represents spatial data, Table represents tabular (non-spatial) data, and Enumeration and Code List represent restricted and non-restricted definition sets.

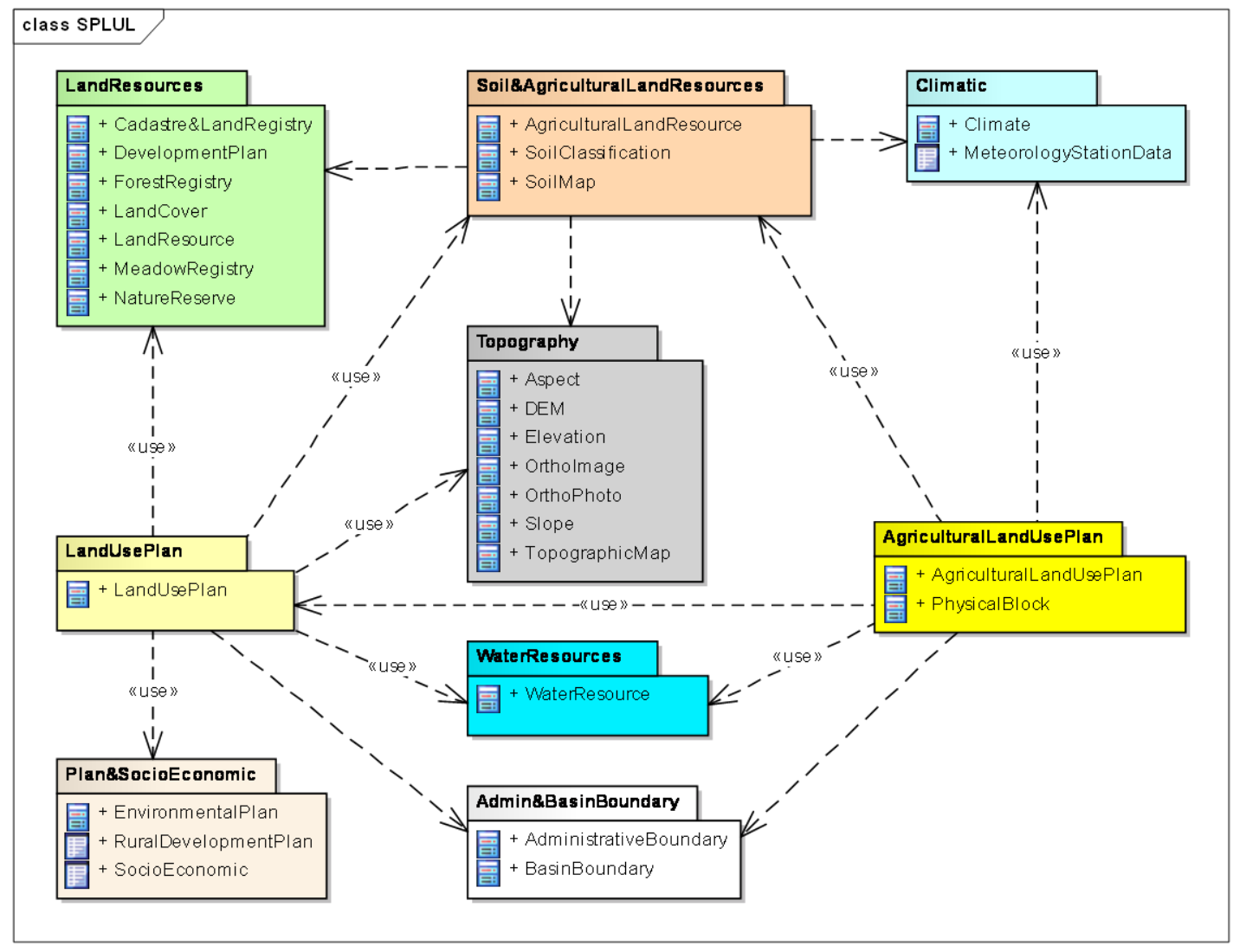

Figure 1- Data groups (packages) and their relations

\subsection{General structure of the model: Packages}

The model is composed of nine data packages (Figure 1). In the sub-sections, the classes in each package and their relation are presented and explained.

\subsection{Land Resources package}

First, the Cadastre \& Land Registry, Development Plan, Forest Registry, Meadow Registry, Nature Reserve and Land Cover classes were defined to represent available data sources in the model. Afterwards, the idea of producing the land resource dataset by using available data sets was reflected in the model design through relations (Figure 2). In order to make the production of land resource data possible by administrative units or basins, the use relation among Land Resource, the Administrative Boundary and the Basin Boundary classes was defined (Figure 2). The data need in this respect was defined with dependency relations among the Land Resource class and other related classes (Figure 2).

For the classification of land resource types, the type attribute in the Land Resource class was designed. To restrict the range of data type of this attribute, the Land Resource Type definition set was defined. Similar definitions were made for other data types for different attributes of other classes (see Figure 2). 
It was envisaged that the agricultural land resource dataset is produced from the land resources dataset. This was reflected in the model with the use relation defined between the Land Resource and Agricultural Land Resource classes. The idea that the agricultural land resource dataset cannot be produced without the land resource dataset was represented in the model with the composition relation (closed diamond) between the two classes (Figure 2).

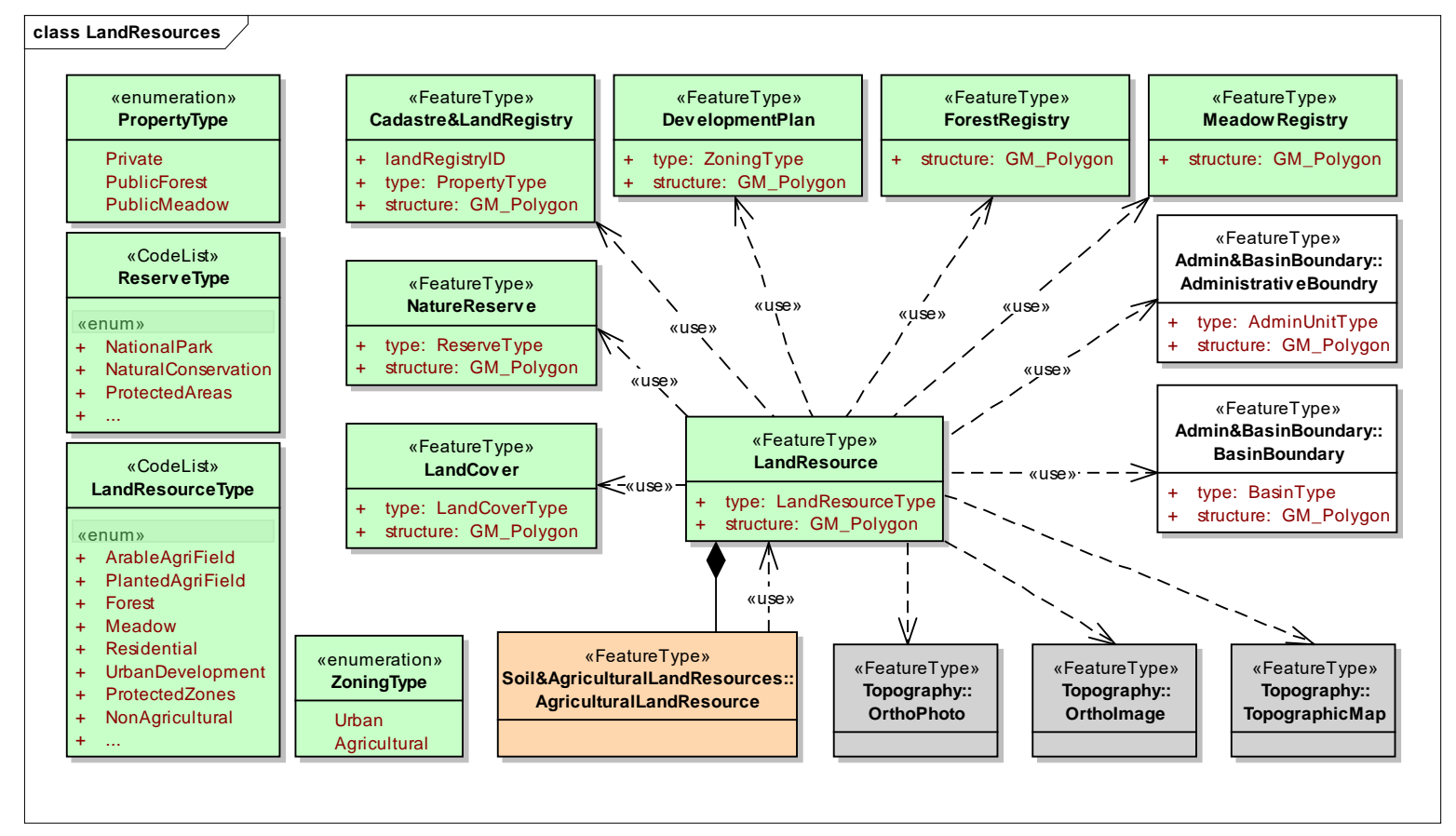

Figure 2- Land resources package

\subsection{Soil \& Agricultural Land Resources package}

For the determination of agricultural land type (classification), soil properties are required. To represent this requirement, the use relation between Agricultural Land Resource and Soil Map classes were defined (Figure 3). The type attribute of Agricultural Land Resource class and the definition set Agricultural Land Type as its data type were defined to represent agricultural land types.

The Soil Map class represents all kinds of soil properties. It also represents all kinds of soil maps produced by using different surveying and mapping methods with its source type attribute (Figure 3). In the Soil Survey Type (Figure 3) definition set, two types of common soil surveying and mapping methods were included. The attribute soil properties (Figure 3 ) of this class is intended to represent all the physical, chemical and biological properties in the soil profile.

In soil surveying and mapping activities, cartographic maps are used for the establishment of mapping units. To reflect this fact in the model, the dependency relations among the Soil Map class and related classes (Topographic Map, Ortho Image and Ortho Photo) were defined (Figure 3).

In order to model the fact that a variety of different soil classification maps may be produced from the same soil map the Soil Classification class was designed. Because this class represents a kind of soil map, the generalization relation between this class and the Soil Map class was used (Figure 3). 


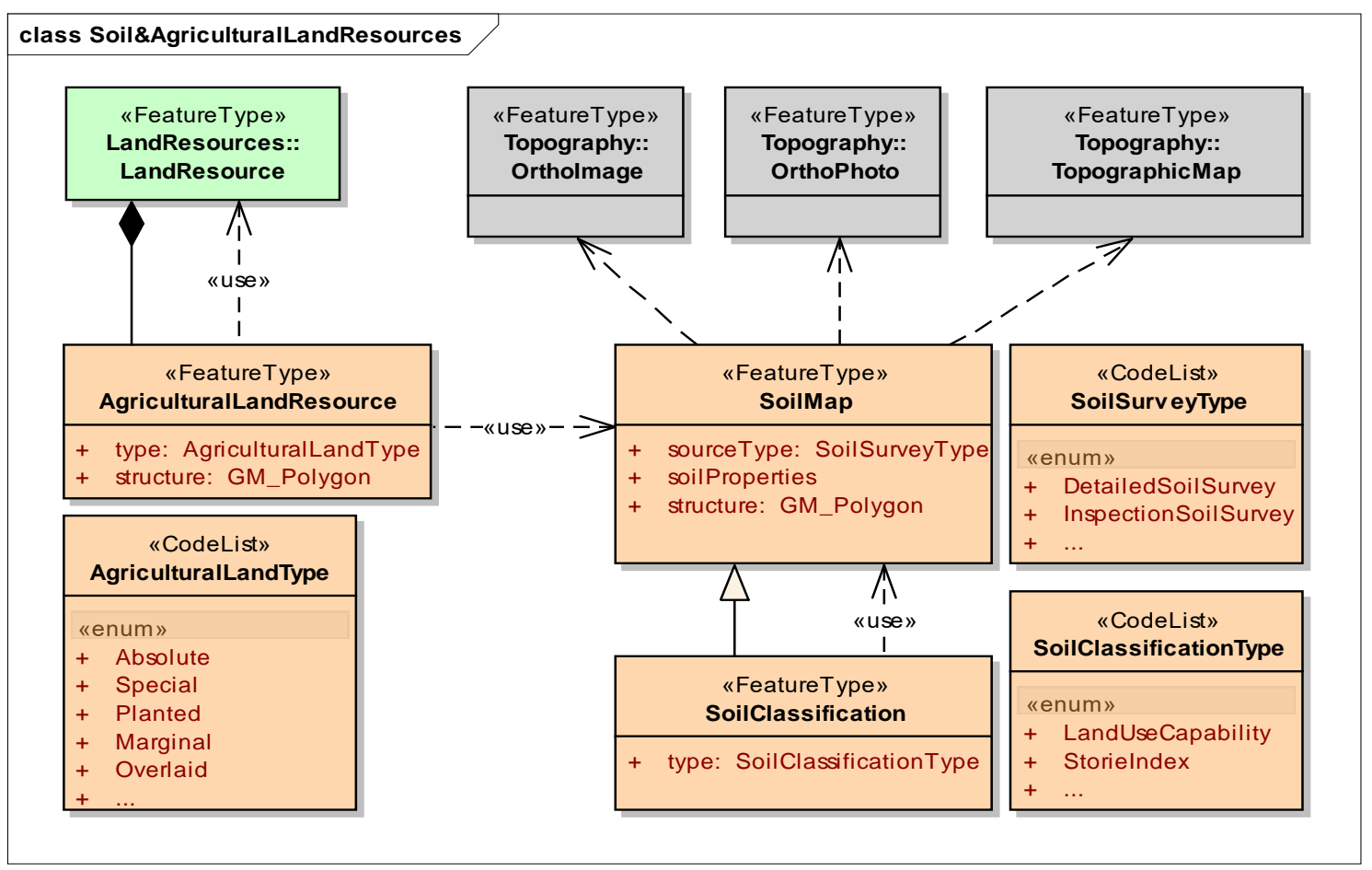

Figure 3- Soil and agricultural land package

\subsection{Topography package}

In this package, classes representing commonly used base maps, namely topographic map, ortho-photo and ortho-image were designed. Additionally, classes representing the Digital Elevation Model (DEM), and also slope and aspect data as the product of DEM were included (Figure 4).

Because the Topographic Map class represents data in different geometries and also in raster formats, the structure attribute of this class was defined as a complex data type (Figure 4). The attribute base scale of this class (Figure 4) represents the original production scale, which reflects data quality.

Because it was envisaged that the DEM dataset is produced from contour lines included in the topographic map, and additionally that the slope and aspect datasets would be produced from the DEM dataset, the use relations were defined between these classes (Figure 4). Because the DEM dataset was envisaged to be in TIN data structure, the data type of its structure attribute was defined as GM_TIN (Figure 4). Because the datasets represented by the Aspect, Slope, Ortho Photo and Ortho Image classes are in cell data structure, their structure attributes were defined as Raster (Figure 4). In the Aspect and Slope classes, class attributes with their Aspect Class and Slope Class data types (Figure 4) were defined to represent different slope and aspect classifications in different applications.

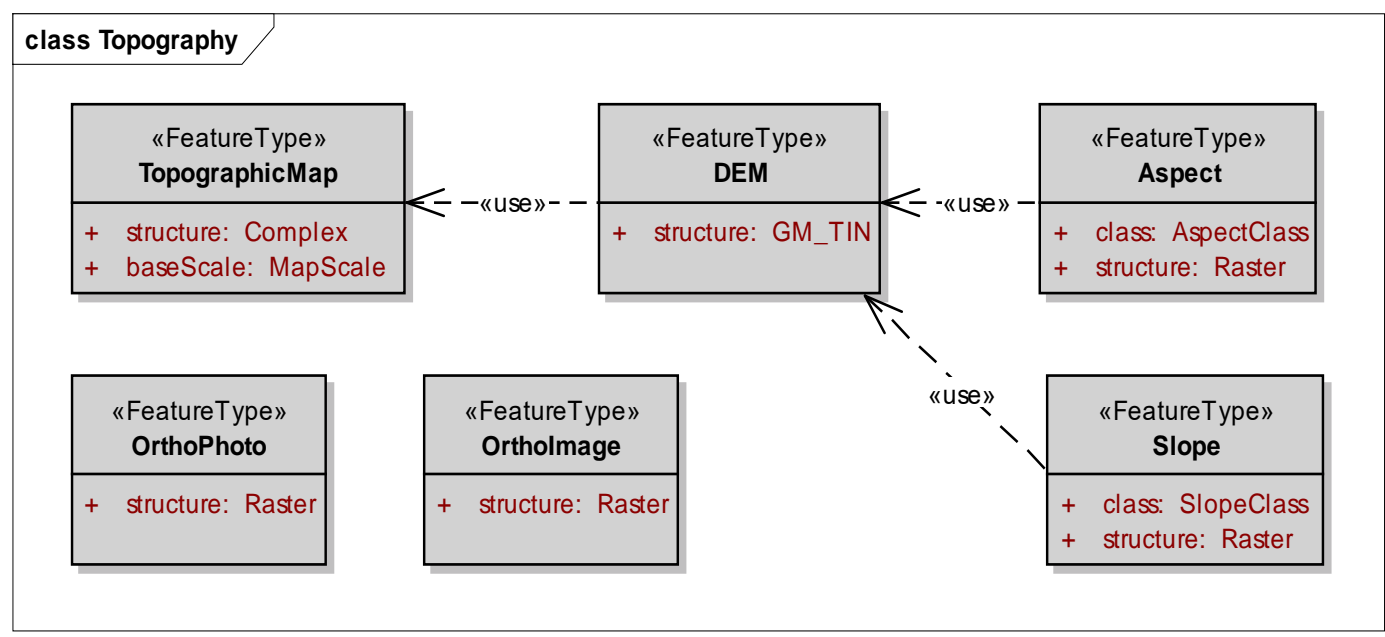

Figure 4- Topography package 


\subsection{Climatic package}

The Meteorology Station Data class (Figure 5) was defined in order to represent raw data recorded at meteorological stations in tabular formats. The attributes of this class were designed to represent climatic data recorded systematically in different periods.

The Climate class was designed (Figure 5) in order to represent geographically continuous climatic data produced by interpolating raw and also derived (average, min and max) data. The type attribute of this class with its data type Climate Data Type (Figure 5) represents the type of data used.

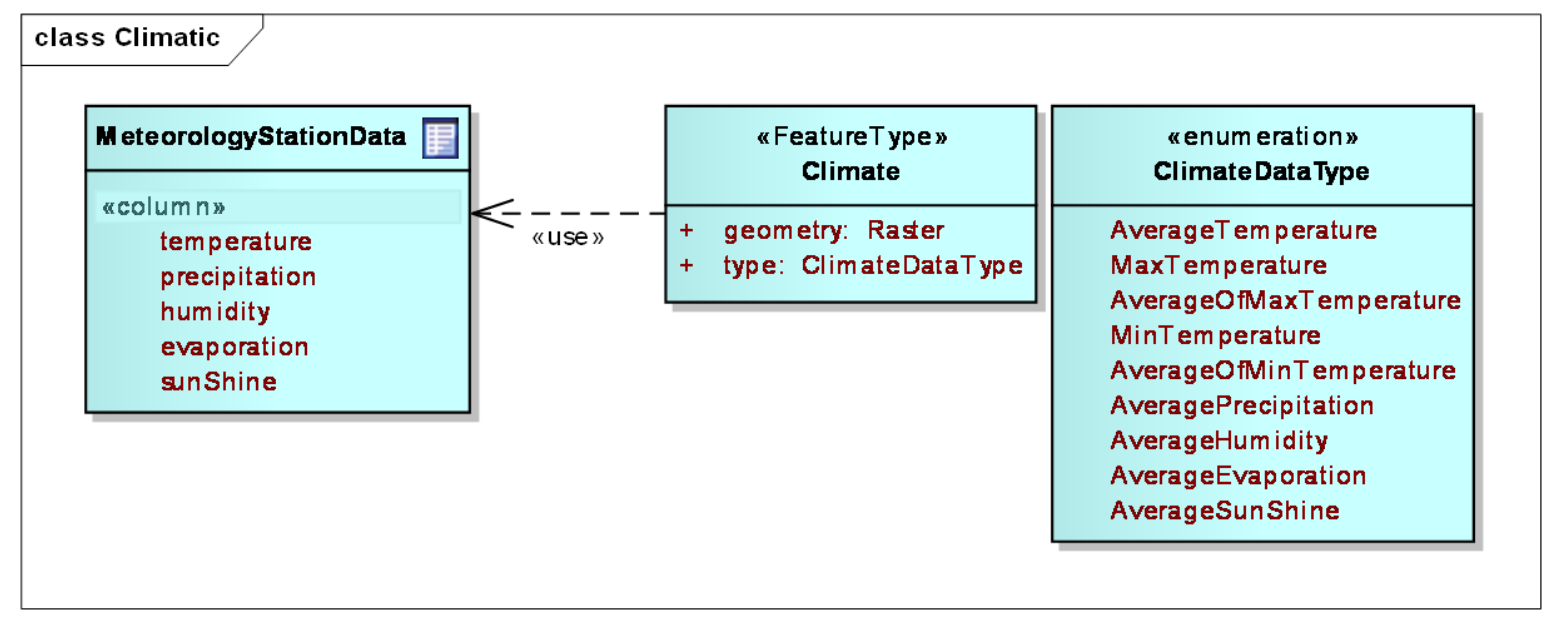

Figure 5- Climatic package

\subsection{Water Resources package}

The Water Resource class (Figure 6) was designed to represent all types of water resources. In order to represent water resources (WR) data in different data structures/geometries (point, line, polygon and network), the WR Structure Type definition set (Figure 6) was specially designed as the data type of structure attribute of this class. Similarly, the irrigation potential attribute was designed for the representation of information on the irrigation potential of all kinds of water resources (Figure 6).

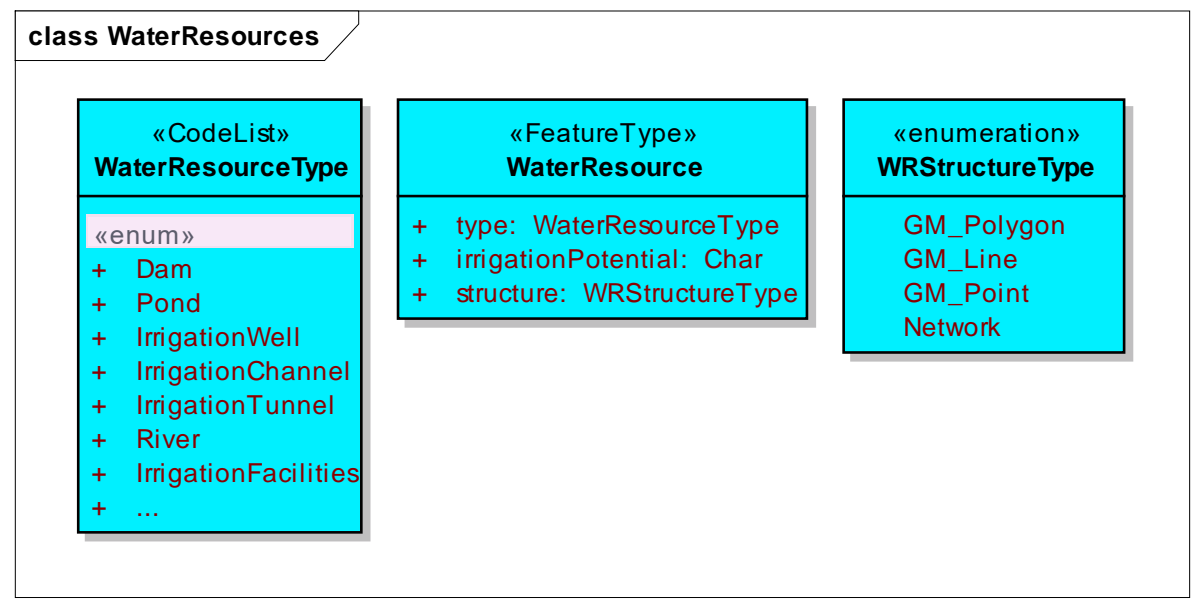

Figure 6- Water resources package

\subsection{Plan \& Socio Economic package}

The Environmental Plan class (Figure 7) was designed to represent the basic information content of environmental plans. To represent planning decisions for basic spatial units in the map, type attribute and, accordingly, the Planned Land Use Type definition set as its data type were designed (Figure 7). Due to planning units with different geometries (polygon, line and 
point), the structure attribute of this class was defined as Complex data type (Figure 7). As for the annex attribute, it represents the planning report (Figure 7).

Prepared as a report without a geographically continuous planning map, the rural development plan was represented by a class structured as an ordinary table without any geometrical structure (Figure 7). In this class, documents and maps related to planning decisions are represented by the attributes Related Documents and Related Maps (Figure 7). Because planning decisions may be linked to administrative units or basin boundaries, the association relations were defined between related classes (Figure 7).

For the representation of non-spatial socio-economic data, the Socio Economic class was designed as an ordinary table (Figure 7). To represent the link between socio-economic data and administrative units, the association relation was defined (Figure 7).

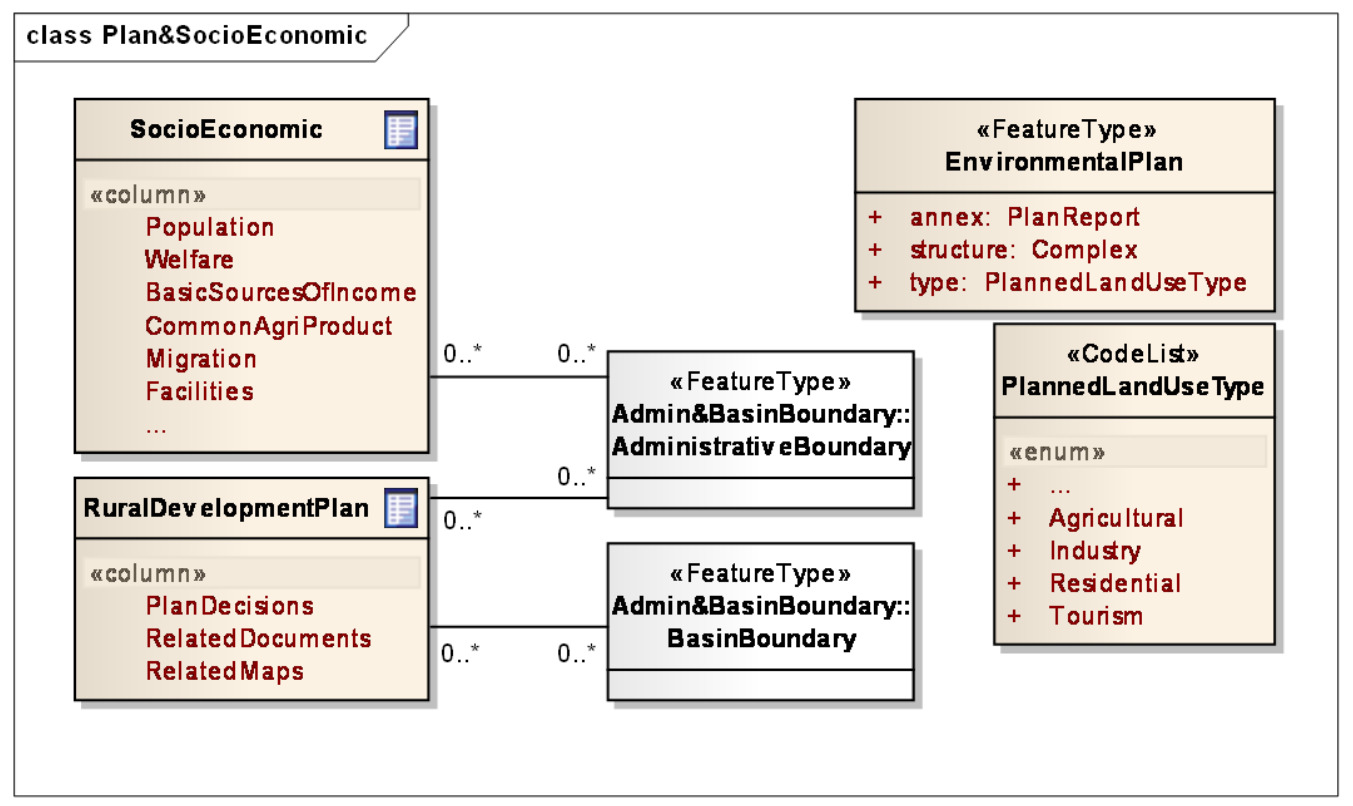

Figure 7- Plan \& SocioEconomic package

\subsection{Admin \& Basin Boundary package}

In order to represent administrative units and basins in different levels, the type attributes for the two classes were designed. For the definition of the data types of these attributes, the Admin Unit Type and Basin Type definition sets were designed (Figure 8).

Topographic data are required for the production of basin boundaries. To represent the use of DEM for this requirement, the use relation between the two classes was defined (Figure 8).

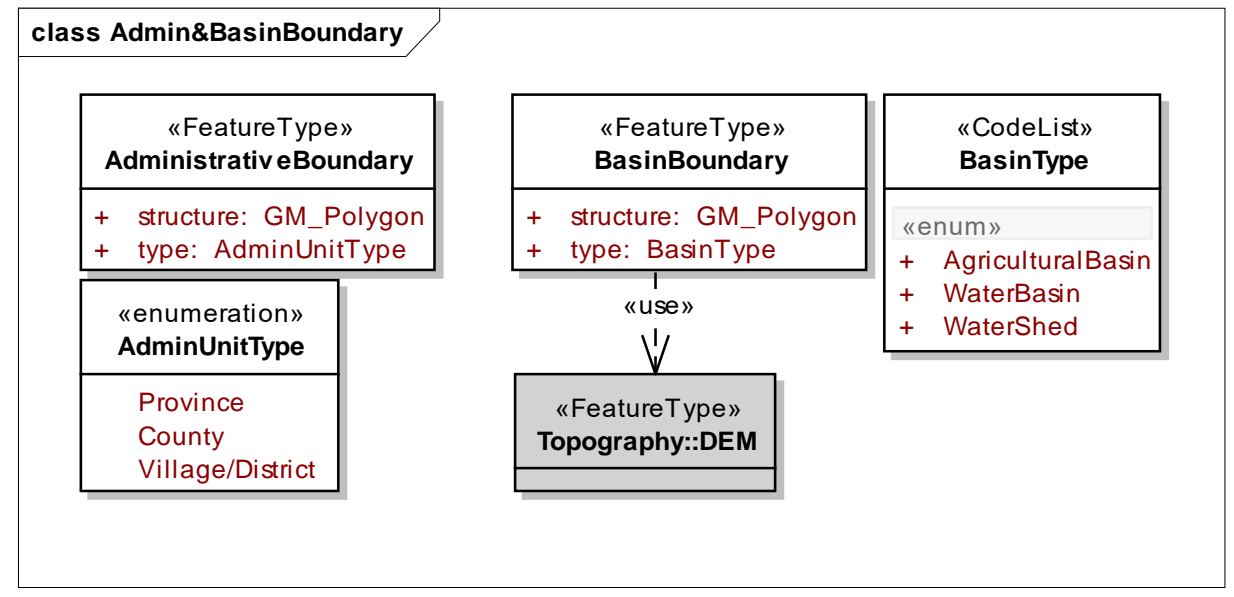

Figure 8- Admin \& Basin package 


\subsection{Land Use Plan package}

The basic dataset in this package is the land use plan, which is to be produced with the implementation of the model. The basic aim of land use planning is to determine sustainable land use decisions in conjunction with national, regional or local needs by considering current land use and all planning criteria. In this context, to represent the relation between current land use and planning decisions, the use relation was defined between the Land Use Plan and Land Resource classes (Figure 9). Indirect relations were defined among the Land Use Plan class and non-spatial data (socio-economic and rural development plan). The use relation is directly defined among the Land Use Plan class and other classes representing data on other planning criteria (soil classification, water resources, environmental plan and topography) (Figure 9).

Class attributes and the Planned Land Use Class definition set, as the data type of this attribute, were designed to represent the land use types proposed in the land use plan (Figure 9). The classes of planning decisions on this definition set were defined by inspiring earlier planning activities of the Ministry of Food, Agriculture and Livestock.

The Land Use Plan (LUP) class represents the most detailed local information. For the production of regional and national plans, the use of generalization methods was envisaged in the model. To represent this vision, the method called generalize was defined in the LUP class (Figure 9). The input data of this method are land use plans at local level, and the output data are regional or national land use plans represented by the Regional LUP or National LUP classes (Figure 9).

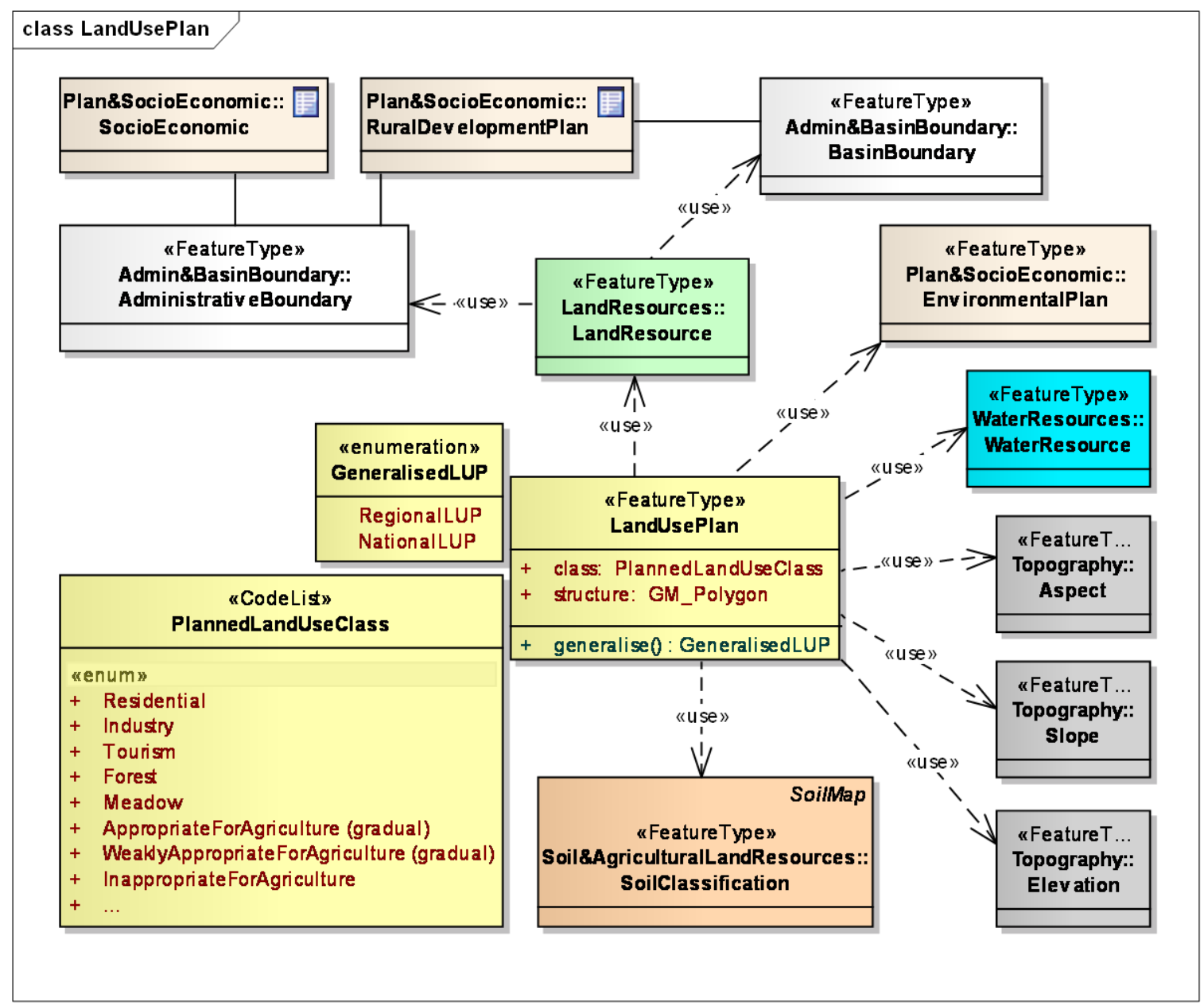

Figure 9- Land Use Plan package

\subsection{Agricultural Land Use Plan package}

The basic datasets in this package are the agricultural land use plan and physical block (Figure 10) which are to be produced by the implementation of the model. The production of these datasets is dependent on the use of data in other datasets. This dependency was represented by the use relation among related classes (Figure 10). The Physical Block class was designed to divide current and planned agricultural land (represented by the Agricultural Land Resource and Land Use Plan classes 
respectively) into physical blocks (Figure 10). Because the spatial planning units of agricultural land use plans are physical blocks, the specialization relation was defined between related classes (Figure 10).

In the Physical Block class, the block name attribute (Figure 10) represents unique block numbers. The Agricultural Land Use Plan class inherits this attribute as well as the geometry attribute by means of the specialization relation (see Figure 10).

The attributes plan decision and suitability (Figure 10) are specific to this class, and they represent proposals or reports and crop type suitability for each planning unit (physical block). To represent the data type of the suitability attribute, the Agricultural Crop Type definition set, which is intended to include all crop types, was designed (Figure 10). When planning decisions for specific crops are needed instead of crop types, a new attribute (e.g. crop suitability) may be added to the model.

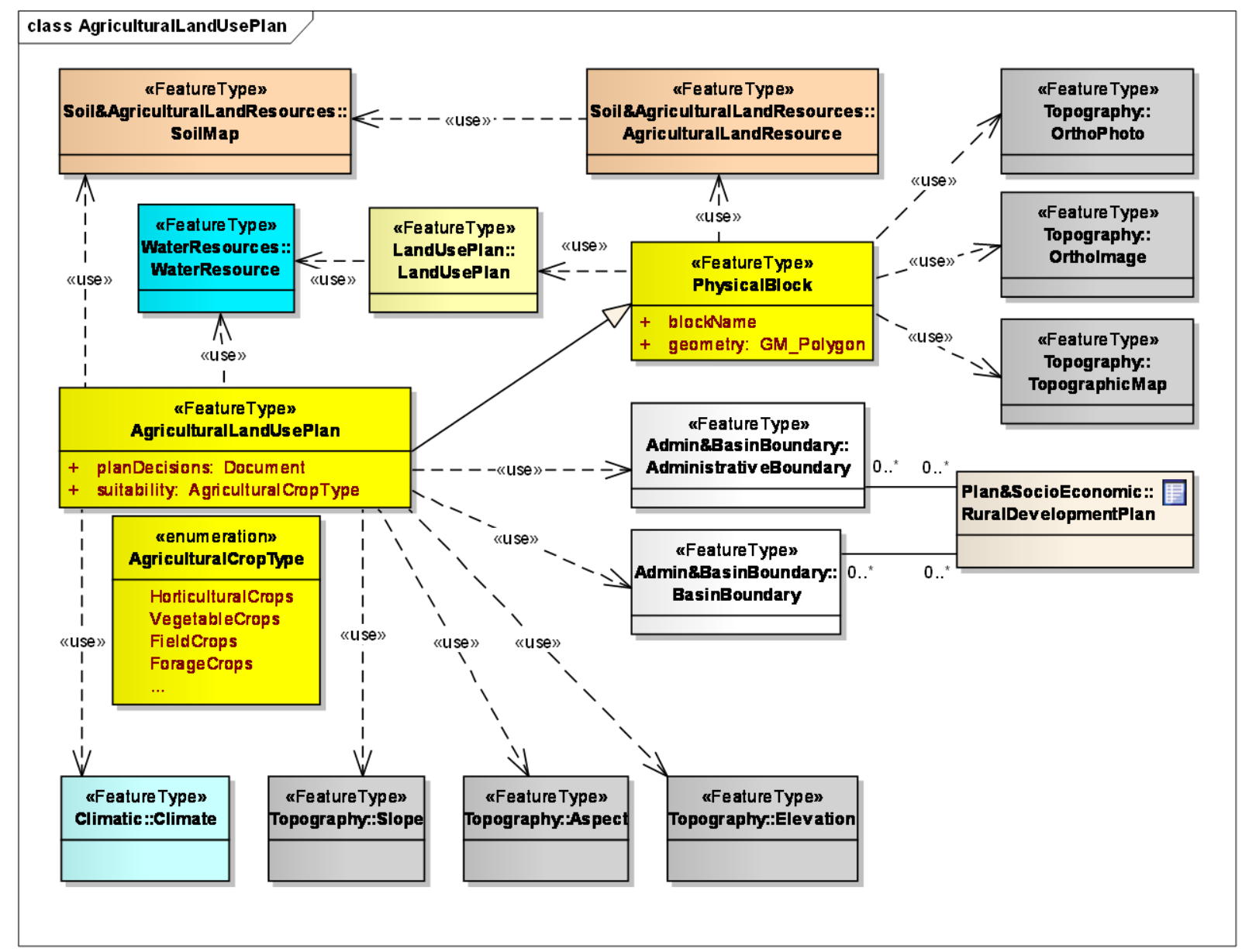

Figure 10- Agricultural Land Use Plan package

\section{Conclusions}

In line with the basic aim of this study, for a standardized production of Land Use Plans and Agricultural Land Use Plans, the proposed data model acts as a means to (1) understand the basic properties of the required data, (2) define the static or dynamic relations among them and also to (3) prevent different interpretations on data requirement or data processing. In the model, the complex natural relations between datasets were presented in a simple way by means of the object-oriented modelling approach using UML notation. However, it is impossible to represent all kinds of natural relations with this approach. For example, use or dependency relations are inadequate to fully model the data processing cycle. Hierarchical order in data processing should also be considered. It is possible to introduce many similar issues on data content, relations, and constraints. Yet, these issues are beyond the scope of this study.

With the model, it was aimed to contribute to the determination and development of implementation standards on rural land planning and management in Turkey. Although all the datasets required both for planning (land use plan and agricultural land use plan) and land management are included in the model, only the plan production process was focused on. The reason for this was the fact that plans are required for all kinds of land management activities. In this context, the model may be further developed for the inclusion of land management practices such as erosion prevention, soil conservation, increasing agricultural productivity and agricultural yield estimates. 
To implement the model, all datasets included in the model should be produced by utilizing the data acquisition or compilation methods for new and available data, respectively. Success in this stage is dependent on many important factors related to the development of National Spatial Data Infrastructure (NSDI) such as data availability, data quality, rules for access to data and responsibilities for data production and maintenance. In this respect, the proposed model may also contribute to the development of the NSDI in Turkey. In fact, Turkish NSDI is its development phase and these kinds of related data infrastructure initiatives proposed by this study have an important role in its further development. Beyond the development of the Turkish NSDI, the proposed model is a good guide to produce a great deal of important data sets represented by classes in the model, especially the ones previously not very well known such as Land Resource, Agricultural Land Resource and Climate. After the data production stage, it is required to have a directive or regulation, which includes all the data processing stages/hierarchies in detail for the production of two basic products of the proposed model - Land Use Plans and Agricultural Land Use Plans. To meet this requirement, the proposed model is envisaged to be the basis for the preparation of such a legal document.

The modelling approach used in this study has been widely used by scientists for the development of ISO/OGC (the International Organization for Standardization / Open Geospatial Consortium) standards or similar tasks and by professionals in their commercial activities. Nevertheless, initiatives are strictly required to extend its use to the implementation of government law related to spatial data management. The proposed model is expected to contribute to such initiatives, especially in Turkey and also in other countries where such initiatives are inadequate.

To better motivate to such a modelling approach, instead of directly using class diagrams (as in this study), the use of activity and use-case diagrams prior to model development could be a convenient method, especially for those who are not adequately informed about the data management activity to be modelled.

\section{References}

Apaydin H, Sonmez F K \& Yildirim Y E (2004). Spatial interpolation techniques for climate data in the GAP region in Turkey. Climate Research 28 (2004): 31-40 https://doi.org/10.3354/cr028031

Bamber J L, Ekholm S \& Krabill W B (2001). A new, high-resolution digital elevation model of Greenland fully validated with airborne laser altimeter data. Journal of Geophysical Research 106(B04): 6733-6745 https://doi.org/10.1029/2000jb900365

Banks J \& Marsden T (2000). Integrating agri-environment policy, farming systems and rural development: Tir Cymen in Wales. Sociologia Ruralis 40(4): 466-480 https://doi.org/10.1111/1467-9523.00161

Bossard M, Feranec J \& Otahel J (2000). CORINE land cover technical guide - addendum 2000. European Environment Agency, Technical Report No 40. Retrieved in August, 11, 2011 from http://www.eea.europa.eu/publications/tech40add

Burrough P A, van Gaans P F M \& Hootsmans R (1997). Continuous classification in soil survey: spatial correlation, confusion and boundaries. Geoderma 77(1997): 115-135 https://doi.org/10.1016/s0016-7061(97)00018-9

Büttner G, Feranec J \& Jaffrain G (2002). CORINE land cover update 2000. European Environment Agency, Technical Report No 89. Retrieved in August, 12, 2011 from http://www.eea.europa.eu/publications/technical_report_2002_89

Cay T \& Iscan F (2011). Land consolidation software algorithm for agricultural reform in Turkey. Asian Journal of Rural Development 1(1): 70-86 https://doi.org/10.3923/ajrd.2011.70.86

Cete M (2008). A land administration system approach for Turkey. PhD Thesis (in Turkish with English abstract), Karadeniz Technical University (Unpublished), Turkey

Dinc U, Senol S, Cangir C, Dinc A O, Akca E, Dingil M, Oztekin E, Kapur B \& Kapur S (2005). Soil survey and soil database of Turkey. In: R J A Jones, B Houskova, P Bullock \& L Montanarella (Eds), Soil resources of Europe, 2nd Ed., European Soil Bureau, JRC, Institute for Environment and Sustainability, Ispra, pp. 371-375. Retrieved in August, 12, 2011 from http://eusoils.jrc.ec.europa.eu/ESDB_Archive/eusoils_docs/esb_rr/n09_EUR20559.pdf

EC (European Commission) (2012). INSPIRE data specifications. Retrieved in June, 29, 2012 from http://inspire.ec.europa.eu/index.cfm/pageid/2

EEA (the European Environment Agency) (2010). Corine Land Cover 2000 seamless vector data - version 13 (02/2010). Retrieved in August, 12, 2011 from http://www.eea.europa.eu/data-and-maps/data/corine-land-cover-2000-clc2000-seamless-vector-database-2

Elands B H M \& Wiersum K F (2001). Forestry and rural development in Europe: An exploration of socio-political discourses. Forest Policy and Economics 3: 5-16 https://doi.org/10.1016/s1389-9341(00)00027-7

Fabris M \& Pesci A (2005). Automated DEM extraction in digital aerial photogrammetry: Precisions and validation for mass movement monitoring. Annals of Geophysics 48(6): 973-988 https://doi.org/10.4401/ag-3247

GDLRC (General Directorate of Land Registry and Cadastre) (2005). Preliminary work report for the establishment of Turkish national geographical information system - Action 47(in Turkish). Retrieved in June, 29, 2012 from http://www.bilgitoplumu.gov.tr/Documents/1/KDEP/050100_Eylem47.pdf

GDLRC (2006). Report on the initial preparation work for the establishment of Turkish national geographical information system (in Turkish). Retrieved in June, 29, 2012 from http://www.turksatglobe.com/Views/Projects/Contents/Files/Eylem36_raporu.pdf

Goeman D, Kantor C, Printzios V, Zloty A \& Mercimek E (2007). Final report for technical assistance for the Ministry of Agriculture and Rural Affairs for the design of a functioning Integrated Administration and Control System (IACS) and a Land Parcel Identification System (LPIS) in Turkey, The European Union's TR0402.08/002 Programme for Turkey. Ankara, Turkey, $162 \mathrm{pp}$

Gun S (2003). Legal state of land consolidation in Turkey and problems in implementation. Pakistan Journal of Biological Sciences 6(15): 1380-1383 https://doi.org/10.3923/pjbs.2003.1380.1383

ISO (2003). ISO 19107 (2003) Spatial Schema. ISO TC211 - Geographic Information/Geomatics, Switzerland

ISO (2019). ISO 19107 (2003) Spatial Schema. ISO TC211 - Geographic Information/Geomatics, Switzerland 
Inan H I (2010). Developing spatial data model as agricultural component of land administration system. PhD Thesis (in Turkish with English abstract), Karadeniz Technical University (Unpublished), Turkey

Inan H I \& Cete M (2007). Agricultural land parcel identification systems and cadastre (in Turkish with English abstract). In: HKMO 11 . Türkiye Harita Bilimsel ve Teknik Kurultayl, 2-6 April, Ankara, Turkey

Inan H I \& Yomralioglu T (2011). Geographical information system model for rural land management. In: HKMO 13. Türkiye Harita Bilimsel ve Teknik Kurultayl, 18-22 April, Ankara, Turkey

Inan H I, Sagris V, Devos W, Milenov P, van Oosterom P \& Zevenbergen J (2010). Data model for the collaboration between land administration systems and agricultural land parcel identification systems. Journal of Environmental Management 91 (2010): 2440 -2454 https://doi.org/10.1016/j.jenvman.2010.06.030

INSPIRE (2007). Drafting Team "Data Specifications" - deliverable D2.3: Definition of Annex Themes and Scope, version 2.0 2007-04-06. Retrieved in June, 16, 2021 from https://inspire.ec.europa.eu/reports/ImplementingRules/inspireDataspecD2_3v2.0.pdf

INSPIRE (2010a). INSPIRE Data Specification on Administrative Units (D2.8.I.4) - Guidelines. Retrieved in June, 16, 2021 from https://inspire.ec.europa.eu/documents/Data_Specifications/INSPIRE_DataSpecification_AU_v3.0.pdf

INSPIRE (2010b). INSPIRE Data Specification on Cadastral Parcels (D2.8.I.6) - Guidelines. Retrieved in June, 16, 2021 from https://inspire.ec.europa.eu/documents/Data_Specifications/INSPIRE_DataSpecification_CP_v3.0.pdf

INSPIRE (2010c). INSPIRE Data Specification on Hydrography (D2.8.I.8) - Guidelines. Retrieved in June, 16, 2021 from https://inspire.ec.europa.eu/documents/Data_Specifications/INSPIRE_DataSpecification_HY_v3.0.pdf

INSPIRE (2010d). INSPIRE Data Specification on Protected Sites (D2.8.I.9) - Guidelines. Retrieved in June, 16, 2021 from https://inspire.ec.europa.eu/documents/Data_Specifications/INSPIRE_DataSpecification_PS_v3.0.pdf

INSPIRE (2013a). INSPIRE Data Specification on Elevation (D2.8.II.1) - Draft Technical Guidelines. Retrieved in June, 16, 2021 from https://inspire.ec.europa.eu/documents/Data_Specifications/INSPIRE_DataSpecification_EL_v3.0.pdf

INSPIRE (2013b). Data Specification on Land cover (D2.8.II.2) - Draft Technical Guidelines. Retrieved in June, 16, 2021 from https://inspire.ec.europa.eu/documents/Data_Specifications/INSPIRE_DataSpecification_LC_v3.0RC2.pdf

INSPIRE (2013c). INSPIRE Data Specification on Orthoimagery (D2.8.III.3) - Draft Technical Guidelines. Retrieved in June, 16, 2021 from https://inspire.ec.europa.eu/documents/Data_Specifications/INSPIRE_DataSpecification_OI_v3.0rc2.pdf

INSPIRE (2013d). Data Specification on Soil (D2.8.III.3) - Draft Technical Guidelines. Retrieved in June, 16, 2021 from https://inspire.ec.europa.eu/documents/Data_Specifications/INSPIRE_DataSpecification_SO_v3.0.pdf

INSPIRE (2013e). Data Specification on Agricultural and Aquaculture Facilities (D2.8.III.9) - Draft Technical Guidelines. Retrieved in June, 16, 2021 from https://inspire.ec.europa.eu/documents/Data_Specifications/INSPIRE_DataSpecification_AF_v3.0.pdf

INSPIRE (2013f). Data Specification on Population Distribution - Demography (D2.8.III.10) - Draft Technical Guidelines. Retrieved in June, 16, 2021 from https://inspire.ec.europa.eu/documents/Data_Specifications/INSPIRE_DataSpecification_PD_v3.0.pdf

INSPIRE (2013g). Data Specification on Area Management/Restriction/Regulation Zones and Reporting Units (D2.8.III.11) - Draft $\begin{array}{llllll}\text { Technical } \quad \text { Guidelines. } & \text { Retrieved } & \text { in } & \text { June, } & 16, & 2021\end{array}$ https://inspire.ec.europa.eu/documents/Data_Specifications/INSPIRE_DataSpecification_AM_v3.0.pdf

Iscan F (2011). The effects of different land reallocation models applied in land consolidation projects on parcel transpositions: Example of Karatepe village, Turkey. Scientific Research and Essays 5(9): 873-882

Jolly W M, Graham J M, Michaelis A, Nemani R \& Running S W (2004). A flexible, integrated system for generating meteorological surfaces derived from point sources across multiple geographic scales. Environmental Modelling \& Software 20 (2005): 873-882 https://doi.org/10.1016/j.envsoft.2004.05.003

Kay S. (2002). Monitoring and evaluation of IACS implementation for the identification of agricultural parcels in Member States of the EU, Base document 2: synthesis of technical alternatives (working draft). Retrieved in June, 29, 2012 from http://mars.jrc.ec.europa.eu/mars/content/download/994/6107/file/TechAlternativesIACS1994.pdf

Kay S \& Milenov P (2007). Status of the implementation of LPIS in the EU Member States. In: Proceedings of 12th MARS PAC Annual Conference, 27-29 November, Toulouse, pp. 41-47

MARA (the Ministry of Agriculture and Rural Affairs) (2006). Rural development report in Turkey. In: International Conference on Agrarian Reform and Rural Development (ICARRD), 7-10 March, Porto Alegre, Brazil, 26 pp

MARA (2011). Rural development plan (2010-2013) (in Turkish). Retrieved in June, 16, 2021 from https://kkp.tarim.gov.tr/KKP20102013.pdf

MARA (2012). Determination of problematic agricultural land and their rehabilitation project. Retrieved in March, 01,2012 from http://www.tugem.gov.tr/document/statiproje.html

Maras H, Asik O, Y1lmaz A \& Kisa A (2011). Turkish national orthophoto information system and work conducted. In: HKMO 13. Türkiye Harita Bilimsel ve Teknik Kurultayl, 18-22 April, Ankara, Turkey

Marsden T \& Sonnino R (2008). Rural development and the regional state: Denying multifunctional agriculture in the UK. Journal of Rural Studies 24: 422-431 https://doi.org/10.1016/j.jrurstud.2008.04.001

Midgley J L, Shucksmith D M, Birnie R V, Geddes A, Bayfield N \& Elston D (2005). Rural development policy and community data needs in Scotland. Land Use Policy 22: 163-174. https://doi.org/10.1016/j.landusepol.2003.08.007

Naldi L, Nilsson P, Westlund H \& Wixe S (2015). What is smart rural development? Journal of Rural Studies 40: 90-101 https://doi.org/10.1016/j.jrurstud.2015.06.006

O'Geen A T, Southard S B \& Southard R J (2008). A revised Storie Index for use with digital soil information. Retrieved in August, 12, 2011 from http://anrcatalog.ucdavis.edu/pdf/8335.pdf

Official Gazette (Turkish Official Gazette) (2005a). Soil Conservation and Land Use Law (in Turkish). No. 25880, 17.07.2005

Official Gazette (2005b). Application Regulation of Soil Conservation and Land Use Law (in Turkish). No. 26024, 15.12.2005

Page-Jones M (2002). Fundamentals of Object-Oriented Design in UML. Addison-Wesley, Dorset House Publishing, New York. ISBN 020169946X

Pasakarnis G \& Meliene V (2010). Towards sustainable rural development in Central and Eastern Europe: Applying land consolidation. Land Use Policy 27: 545-549 https://doi.org/10.1016/j.landusepol.2009.07.008

Sarisamur F \& Kilic S (2011). Potential land use planning and agricultural land suitability classification of Bala Agricultural Farm, AnkaraTurkey. International Journal of the Physical Sciences 6(10): 2586-2592 
UN (United Nations), 2019. World urbanization prospects: The 2018 revision. United Nations Department of Economic and Social Affairs ISBN: 978-92-1-148319-2. Retrieved in June, 16, 2021 from https://population.un.org/wup/Publications/Files/WUP2018-Report.pdf

Unver I H O (1997). South-eastern Anatolia integrated development project (GAP), Turkey: An overview of issues of sustainability. Water Resources Development 14 (2): 187-207 https://doi.org/10.1080/07900629749827

van der Ploeg J D, Renting H, Brunori G, Knickel K, Mannion J, Marsden T, de Roest K, Sevilla-Guzman E \& Ventura F (2000). Rural development: From practices and policies towards theory. Sociologia Ruralis 40(4): 391-408 https://doi.org/10.1111/1467-9523.00156

Volker K (1997). Local commitment for sustainable rural landscape development. Agriculture, Ecosystems and Environment 63: 107-120 https://doi.org/10.1016/s0167-8809(97)00006-6

Züblin M, Fischer L \& Eisenbeiss H (2008). Combining photogrammetry and laser scanning for DEM generation in steep high-mountain areas. The International Archives of the Photogrammetry, Remote Sensing and Spatial Information Sciences XXXVII(B6b): 37-44

(C) 2021 by the authors. Licensee Ankara University, Faculty of Agriculture, Ankara, Turkey. This article is an open access article distributed under the terms and conditions of the Creative Commons Attribution (CC BY) license (http://creativecommons.org/licenses/by/4.0/). 